\title{
Level of Sustainable Green Practices at Pantai 2 Sewage Treatment Plant, Klang Valley, Malaysia
}

\author{
Raman Mariyappan ${ }^{1}$
}

\begin{abstract}
The level of sustainable green practices (energy efficiency, indoor environmental quality, sustainable site planning \& management, materials \& resources, water efficiency and innovation) among developers is indeed an aspect that needs immediate attention in the non-residential projects in the Klang Valley, Malaysia. Sustainable green practices promotes positive activities that will ensure energy efficiency, water efficiency, fairness, effectiveness, divergence, less disparity, less discrimination, inexpensive, reasonable priced, pleasant design, serenity, mutual comfort and many other characteristics to the future for the construction industry. The developer must converge at a point where no one is short changed due to limitation in the implementation mechanism of sustainable green practices in the non-residential projects. The aim of this research is investigate the extent of sustainable green practices in the Pantai 2 Sewage Treatment Plant. In order to achieve the research aims, the specific objectives of this research is divided into the following sequential steps: identification of the existing sustainable practices implemented in Pantai 2 STP ; Model, assess and compare against common benchmarks the Energy Efficiency for the administrative building; Model, assess and compare against common benchmarks the Water Efficiency for the administrative building; and assessment of the replicability of the sustainable practices for other STP plants. Quantitative and qualitative design were used, in which a total of 381 public respondents with systematic random sampling were employed and a total of eight organizational sampling were used. Briefly the result shows evidence of existing level of energy efficiency, solar power panels for the parking bays, water efficiency from rain water harvest and the utilization of eco-park for public activities. Surprisingly, 87 percent of the respondents reported of not knowing the existence of underground sewage treatment plant at Pantai 2.
\end{abstract}

Keywords: sustainable green practices, non-residential projects, developer, energy efficiency, water efficiency

\section{Introduction: Problem Statement and Objectives}

Sustainable Development (SD) is the future and must be included in every aspect of human developments. Concepts of Green Building (GB), slowly creeping into construction sector, which is good omen and blessing for the construction sector. Actually the SD and GB should be embedded in the construction and maintenance of STPs in Klang Valley. STP's always warranted little attention due to negative perception and conventional method of treating the sewage sledges. As societies moved from nomadic cultures to building more permanent sites, the concern over waste (solid and wastewater) disposal became an important concern. As we will see it has been an issue that has been dealt with many different ways and knowledge has been lost and regained. When groups were living as hunters and gathers, the natural decomposition dealt with refuse and human wastes naturally. What we must understand "until recently, wastewater sanitation focused on minimizing health risks, primarily infectious diseases. More recently, the scope of wastewater management issues has broadened to include chronic 
health risks and environmental concerns" (Burks \& Minnis, 1994). Research on STPs has proven the potential of water and energy efficiency at global level. Malaysia is too moving in the direction by building integrated facilities for STP, such as Pantai 2 STP. STP's comes under SPAN (NATIONAL WATER SERVICES COMMISSION), which is a technical and economic regulatory body for the water supply and sewage services in Peninsular Malaysia and Federal Territories of Putrajaya and Labuan. The Commission regulates all entities in the water supply and sewage services industry including public and private water supply and sewage services operators, water supply and sewage contractors, permit holders and suppliers of water and sewage products. SPAN regulates the water services industry in accordance to the Water Services Industry Act 2006 (Act 655) which was enforced on 1st January 2008. The maintenance of STP's comes under Indah Water Konsortium Sdn Bhd, a national sewage company in Malaysia. IWK is wholly government-owned company which has been entrusted with the task of developing and maintaining a modern and efficient sewage system for West Malaysia. Pantai 2 STP needs investigation due to its billing as one of the first STP related to GB and SDP. Further, there is no independent study showing the energy efficiency and water efficiency of Pantai 2 STP. This is the challenge this study need to encounter.

Based on the issues discussed, the aim of this study is to develop "A model for Sustainable Green Practices among Developers and Maintenance Agency”. In order to achieve this research aims, thus the objectives of the research are divided into three progressive steps; to assess the level of sustainable green practices among developer and maintenance agency in the Pantai 2 Regional Sewage Treatment Plant; to analyse the level of sustainable green practices among developer and maintenance agency in the Pantai 2 Regional Sewage Treatment Plant; and to design the measures to be taken to encourage the level of sustainable green practices among developer and maintenance agency in the Pantai 2 Regional Sewage Treatment Plant. Thus, the study will concentrate on revealing existing SGP and encounter with suggestions for future developments.

\section{Findings}

\section{A. Identification of Existing Green Strategies}

\section{i. Biogas Plant}

Methane gas, which is a by-product of the treated sludge, can be processed by the biogas generator to produce ancillary power of upwards to $700 \mathrm{~kW}$. Recycling the Plant's treated effluents is a source of fertilisers for landscaping. The biogas plant in P2STP is designed to yield $9600 \mathrm{~m} 3$ of biogas daily. On a regular basis, these gases are used by the CHP engine to produce electric power worth $660 \mathrm{kWe}$ from the spark ignition engines. Any remaining gases will be utilized as fuel to produce hot water for the sludge digesting process.

ii. Photovoltaic Plant

Photovoltaic cells are installed in the vicinity (as shading on the parking bays) to contribute to the energy needs of the STP, supplying 200kW of energy daily.

iii. Rainwater Harvesting

Restroom amenities and landscaping uses water acquired via rainwater harvesting, approximately collecting $80 \mathrm{~m} 3$ water per day. 
A further $2460 \mathrm{~m} 3$ of treated water, generated via multiple filtration and reverse osmosis, is produced by treating bio-effluents for the use of the plant.

iv. Bio-effluent pool

Wastewater can be treated to generate bio-effluents, bio-solids, and bio-gas - products with value-adding properties. They have the potential to be commercialized as sustainable and recyclable products. Bio-effluent pool acts as a window to the plant below.

v. Skylight

Skylights not only connect the building to the sky, but they also provide sufficient natural light to reduce the use for artificial lighting during normal hours of the building operation.

vi. Eco Park

A 12 hectares of recreational park is built above the sewage treatment plant. It consists of sport facilities such as football field, futsal court, volleyball court, takraw court, badminton court, basketball court, jogging track together with cafeteria and a multipurpose hall.

\section{B. Energy Efficiency}

A range of 22 design enhancements are proposed and simulated to assess their effectiveness in reducing the energy consumption of Pantai 2 STP Administrative Building. Every step in improving the building performance in the simulations is key in improving the energy consumption. Industry-standard uses BEI as a measure for building performance. BEI stands for Building Energy Intensity, and can be measured by $\mathrm{kWh} / \mathrm{m} 2 /$ year. It is used for all major sustainable rating systems in Malaysia. It dictates the amount of energy consumed per area of the building. The building facade has a WWR (window-to-wall-ratio) of $21 \%$. Whilst letting natural daylight in the spaces, windows are also a source of heat-gains in buildings as they let more heat to enter.

i. Methodology

A notional base building was defined using conventional code complying building construction practices. This baseline building is simulated using a dynamic energy modelling software to establish the benchmark energy performance. Design improvement scenarios are developed and applied incrementally to the building. A record of the energy consumption is then created for every output of each scenario. This means the cumulative performance of the building is recorded in such a way that allows for comparison. It will also account for all the improvements from start to end. Energy Plus v8 (US, DOE) is the engine used to create this dynamic energy simulation. The simulation takes into account the building physique, local climate data, source of heat gains, as well as the building systems and HVAC.

ii. Weather Data

Malaysia has a tropical climate, like the rest of Southeast Asia. The sun shines brightly the whole year, with a very consistent ambient temperature which doesn't fluctuate often (rarely straying from $25 \mathrm{oC}-31 \mathrm{oC}$ ). Constant solar radiation occur due to its proximity to the equator, and humidity is at $80 \%$ year round. The simulation was based on hourly Climate Design Data from 2009 ASHRAE Handbook, based on statistics from 20 years measurements at the Kuala Lumpur International Airport. The project is located within $35 \mathrm{~km}$ from KLIA which makes the measurements sufficient for accurately representing 
the site's climatic conditions.

iii. Baseline Building

Our baseline model is set up to comply with the local building design practices and codes. It meets the required criteria for the Malaysian Standard 1525 (MS 1525) for Energy Efficiency in non-residential buildings, the building envelope and engineering required. Simulation results from Baseline building represents Case 1 (Benchmark) and is equal to BEI $=120.45 \mathrm{kWh} / \mathrm{m} 2 /$ year. GBI recognises that baseline BEI for offices is approximately $220 \mathrm{~kW} / \mathrm{m} 2 /$ year. This is based on Malaysia average energy use in office buildings derived from actual performance data that include various office building typologies and age.

iv. Passive Strategies

The following table (Table 1) contains the simulation outputs by the altering of passive features and methods, such as natural light harvesting, building insulation, well-insulated glazing, and air-tightness of the structure.

\begin{tabular}{|l|l|c|c|}
\hline \multicolumn{3}{|c|}{ BEI and Reduction Percentages for Case 1 (Baseline) to Case 9 } \\
\hline & Situation & BEI (kW/m2/y) & Reduction \\
\hline 1 & Baseline case & $\mathbf{1 2 0 . 4 5}$ & - \\
\hline 2 & Roof Insulation $50 \mathrm{~mm}$ & $\mathbf{1 2 0 . 0 6}$ & $0.32 \%$ \\
\hline 3 & Roof Insulation $100 \mathrm{~mm}$ & $\mathbf{1 1 9 . 9 6}$ & $0.41 \%$ \\
\hline 4 & Wall Insulation $25 \mathrm{~mm}$ & $\mathbf{1 1 9 . 7 2}$ & $0.61 \%$ \\
\hline 5 & Wall Insulation $50 \mathrm{~mm}$ & $\mathbf{1 1 8 . 4 9}$ & $1.63 \%$ \\
\hline 6 & Glazing U-value from 5.84 to 4.26/0.44/0.27 & $\mathbf{1 1 5 . 9 5}$ & $3.74 \%$ \\
\hline 7 & Glazing U-value from 4.26 to 3.53/0.36/0.27 & $\mathbf{1 1 4 . 5 6}$ & $4.89 \%$ \\
\hline 8 & Glazing U-value from 3.53 to 2.00/0.25/0.16 & $\mathbf{1 1 3 . 0 4}$ & $6.15 \%$ \\
\hline 9 & Nat-Ventilated Corridor/Lobby & $\mathbf{1 0 4 . 9 8}$ & $12.84 \%$ \\
\hline
\end{tabular}

Table 1 showed that the implementation of passive features reduces the BEI down to $105 \mathrm{kWh} / \mathrm{m} 2 /$ year, which is a reduction of $13 \%$ from the baseline Case 1 .

\section{Energy Efficiency - Passive Strategies}

i. Insulation of building structures

Under baseline scenario, no part of the building is insulated. Case 2 and 3 applies polyurethane insulation on the roof at a thickness of $50 \mathrm{~mm}$ and $100 \mathrm{~mm}$ respectively. The results show a minimal difference between the simulations $(0.33 \mathrm{~W} / \mathrm{m} 2 \mathrm{~K}$ U-value for $50 \mathrm{~mm}$ insulation and $0.19 \mathrm{~W} / \mathrm{m} 2 \mathrm{~K}$ for $100 \mathrm{~mm}$ insulation). This means that a $50 \mathrm{~mm}$ insulation is good enough in this case. Simulations proceeded to the insulation of walls, following the same concept but at a different thickness $-25 \mathrm{~mm}(0.56 \mathrm{~W} / \mathrm{m} 2 \mathrm{~K})$ for Case 4 and $50 \mathrm{~mm}(0.33 \mathrm{~W} / \mathrm{m} 2 \mathrm{~K})$ for Case 5 .

ii. Glazing Performance

Case 6 replaces standard glazing (U-value $5.84 \mathrm{~W} / \mathrm{m} 2 \mathrm{~K}$, Solar Heat Gain Coefficient (SHGC) of 0.70 , and Visual Transmittance (VT) of 0.60 ) with one that has better properties (U-value $4.26 \mathrm{~W} / \mathrm{m} 2 \mathrm{~K}$, SHGC 0.44, VT 0.27). Case 7 reduces the glazing Uvalue to $3.53 \mathrm{~W} / \mathrm{m} 2 \mathrm{~K}$ and SHGC of 0.36 . In Case 8 , double-glazing is used for the 
windows and glass doors, which has a U-value of $2.00 \mathrm{~W} / \mathrm{m} 2 \mathrm{~K}$, SHGC of 0.25 and VT of 0.16. Reduction in SHGC is included by the use of glass specification with tinted Low-E coating, and double glazing can bring down the U-value to 2.00 or even less. The reduction brought by glazing shows a significant reduction as compared to the previous simulations.

iii. Natural Ventilation

In Case 9, the corridors and the adjacent spaces are made to be naturally ventilated. These spaces are not regularly occupied, therefore the switch for natural ventilation mode does not impact the overall comfort level of the office spaces. This change would bring along an even comparatively large reduction, reducing BEI by an additional 6\%, reaching $12 \%$ overall savings.

\section{Energy Efficiency - Lighting Strategies}

i. Lighting Strategies

A selection of energy-efficient luminaries allows for large reductions of energy via LDP (lighting power density). Different values are attached to different areas based on their purpose and the standards dictated by internationally-recognized building codes.

\begin{tabular}{|l|l|c|c|}
\hline \multicolumn{3}{|l|}{ BEI and Reduction Percentages for Case 1 (Baseline) to Case 9 } \\
\hline & Situation & BEI (kW/m2/y) & Reduction \\
\hline 10 & Office LDP from 14/15 to $9 \mathrm{~W} / \mathrm{m} 2$ & $\mathbf{9 7 . 9 0}$ & $18.72 \%$ \\
\hline 11 & Office LDP from 9 to $7 \mathrm{~W} / \mathrm{m} 2$ & $\mathbf{9 5 . 4 5}$ & $20.75 \%$ \\
\hline 12 & Elec/Mech LDP from 16 to $5 \mathrm{~W} / \mathrm{m} 2$ & $\mathbf{9 2 . 0 3}$ & $23.60 \%$ \\
\hline 13 & Elec/Mech LDP from 5 to $3 \mathrm{~W} / \mathrm{m} 2$ & $\mathbf{9 1 . 4 1}$ & $24.11 \%$ \\
\hline 14 & Walkway Corridor LDP from 20 to $9 \mathrm{~W} / \mathrm{m} 2$ & $\mathbf{8 7 . 3 2}$ & $27.50 \%$ \\
\hline 15 & Walkway Corridor LDP from 9 to $7 \mathrm{~W} / \mathrm{m} 2$ & $\mathbf{8 6 . 1 8}$ & $28.45 \%$ \\
\hline 16 & Restroom LDP from 20 to $9 \mathrm{~W} / \mathrm{m} 2$ & $\mathbf{8 4 . 0 7}$ & $30.20 \%$ \\
\hline
\end{tabular}

The implementation of all the lighting improvement strategies will further reduce the

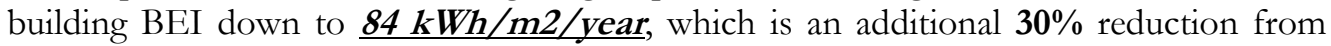
the baseline Case 1.

ii. Office Lighting Power Density (LPD)

$15 \mathrm{~W} / \mathrm{m} 2$ is dictated to be the maximum LPD an office space is allowed by the Malaysian Standard 1525. Cases 10 and 11 brings the value down to 9 and $7 \mathrm{~W} / \mathrm{m} 2$ respectively. As the main body of the building, this can bring down large savings.

iii. Walkway/Lift Lobby LPD

Large reductions can also be achieved by the use of better lighting fixtures for the Walkway and Lobby. This is because their LPDs are reduced to 9 and $7 \mathrm{~W} / \mathrm{m} 2$ (just like the offices) from the maximum allowable LDP of $20 \mathrm{~W} / \mathrm{m} 2$, bringing in drastic energy savings.

iv. Electrical/Mechanical Rooms LPD

Case 12 and 13 showed that the LDP for the Electrical and Mechanical rooms reduced to 5 and $3 \mathrm{~W} / \mathrm{m} 2$, from initial LDP of $16 \mathrm{~W} / \mathrm{m} 2$, which is a value approved by ASHRAE. This is reduced to meet but not exceed the MS 1525 standards.

v. Restroom LPDs Toilet Lighting Power Density 
Case 16 optimises lighting power at the toilets from $20 \mathrm{~W} / \mathrm{m} 2$ to $9 \mathrm{~W} / \mathrm{m} 2$. All these changes can be achieved by using more energy-efficient lights, such as LED bulbs.

\section{E. Energy Efficiency - Cooling Strategies}

i. Air-conditioning Strategies

As the building component in charge of cooling the regularly occupied spaces (largest energy consumption for buildings), there are many factors to be played with the building's air-conditioning.

\begin{tabular}{|l|l|c|c|}
\hline \multicolumn{3}{|l|}{ BEI and Reduction Percentages for Case 1 (Baseline) to Case 9 } \\
\hline & Situation & BEI (kW/m2/y) & Reduction \\
\hline 17 & Fan Efficiency from 65\% to 70\% & $\mathbf{8 3 . 9 6}$ & $30.30 \%$ \\
\hline 18 & Heat Recovery 0 to 50\% & $\mathbf{8 0 . 6 5}$ & $33.05 \%$ \\
\hline 19 & Pump motor efficiency from 0.6 to 0.9 & $\mathbf{8 0 . 3 1}$ & $33.32 \%$ \\
\hline 20 & Chiller COP from 2.7 to 3.3 & $\mathbf{7 5 . 1 3}$ & $37.63 \%$ \\
\hline 21 & Chiller COP from 2.3 to 4.3 & $\mathbf{6 9 . 9 0}$ & $41.97 \%$ \\
\hline 22 & Chiller COP from 4.3 to 5.3 & $\mathbf{6 6 . 6 3}$ & $44.68 \%$ \\
\hline 23 & Chiller COP from 5.3 to 6.3 & $\mathbf{6 4 . 4 0}$ & $46.53 \%$ \\
\hline
\end{tabular}

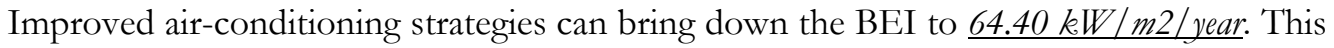
value is now very close to being half of the baseline, being a $46 \%$ energy reduction.

ii. Efficiency of Fans:

Case 17 increases the efficiency of fans to $70 \%$ from $65 \%$, which can be achieved by implementing air foil-type fan blades.

iii. Pump motor efficiency

Implementing an IE3 motor increases the pump's efficiency by $30 \%$, bringing it up to $90 \%$ from the $60 \%$ achieved with regular IE2 motors.

iv. Heat Recovery

Case 18 introduces a heat-recovery system. This is useful in gathering back the released energy that was discarded by the exhaust system, moving them to the outdoor air intake system on the building roof. This heat-recovery system is set to have an efficiency of $50 \%$ (for both sensible and latent load).

v. Chiller COP

The largest consumer of energy in the air-conditioning system is the chiller. With the maximum COP of 7, Malaysia's standard chillers has a COP of 3 (or less). More efficient chillers available in the market may reach COPs of 5-6. Case 20-23 plays with a range of COPs available to choose from.

F. Water Efficiency - Introduction

Three water models were developed to assess the effect of efficient water fixtures as well as rainwater harvesting. The three cases are: 1) the benchmark case, 2) the current building case and 3) the optimised design case. The benchmark case is based on Green Building Index (GBI) standard flow and fixtures rates. As in the energy simulation, these cases are key in developing the building performance against a benchmark, by looking at potential ways to reduce water consumption. The water consumption for this building is reported in $\mathrm{m} 3$ and makes a distinction between total water usage, as well as the amount 
of potable water usage. Potable water can be reduced by more efficient water fixtures and fittings as well as the use of alternative water sources.

i. Methodology

Approximate usage of water for each type of consumption can be calculated by our water efficiency software. A diagram of water usage and balancing will be generated to visualize building water consumption. This helps in deciding the scenarios of water consumption and strategies to increase efficiency in water management. Commonlyfound water fixtures which has flow rates considered to be efficient meets WEPLS ratings (SPAN), where savings are measured from baseline rates (BS 6700).Landscape irrigation has been kept out of scope for this simulation and the focus has been on the water usage for the administrative office building.

ii. Inputs to "Benchmark" Model

a. Occupancy \& Schedules:

For the all cases the water demand is based on assumed office occupancy of 30 FTE (50\% male / 50\% female), working standard office hours. This are input to calculate the daily and annual water consumption.

b. Water Fitting:

For the benchmark case, generic water efficient fixtures with efficiency rated flow-rates are taken. WC single flush: 6/flush, Urinal: $3.8 \mathrm{~L} /$ flush, Basin tap: $9 \mathrm{~L} / \mathrm{min}$, Ablution tap: $8 \mathrm{~L} /$ minRainwater Harvesting: not included in benchmark case.

iii. Outputs of "Benchmark" Model

- Daily potable water consumption 967 liter

- Annual water consumption $270 \mathrm{~m} 3$.

- $64 \%$ of all water use from toilet flushing

\begin{tabular}{|c|c|c|c|c|c|}
\hline \multirow{2}{*}{\multicolumn{2}{|c|}{$\begin{array}{l}\text { Design Case } \\
\text { Water Efficient Fittings }\end{array}$}} & \multicolumn{4}{|c|}{ Consumption } \\
\hline & & \multirow{2}{*}{$\begin{array}{c}\text { Flow } \\
6\end{array}$} & \multicolumn{2}{|c|}{ Duration } & \multirow{2}{*}{$\begin{array}{r}\text { L per day } \\
360\end{array}$} \\
\hline Water closet 1 & Full flow & & \multirow{2}{*}{1} & \multirow{2}{*}{ flush } & \\
\hline Single flush & Reduced & 0 & & & - \\
\hline \multirow[t]{2}{*}{ Water Closet } & Full flow & 6 & \multirow{3}{*}{1} & \multirow{3}{*}{ flush } & 90 \\
\hline & Reduced & 6 & & & - \\
\hline Urinal 1 & Urinal 1 & 3.8 & & & 171 \\
\hline Bib tap 1 & Bib tap 1 & 8 & 5 & secs & 10 \\
\hline Basin tap 1 & Basin ta| & 9 & 12 & secs & 216 \\
\hline Sink tap & & 9 & 15 & secs & - \\
\hline Ablution tap 1 & Ablution & 8 & 30 & secs & 120 \\
\hline Shower & & 13 & 360 & secs & - \\
\hline \multirow[t]{2}{*}{ Bath } & & 176 & 1 & use & - \\
\hline & & \multicolumn{3}{|c|}{ Sub-total (L) } & 967 \\
\hline \multicolumn{2}{|c|}{ Fixtures } & Flow & \multicolumn{2}{|c|}{ Duration } & L/day \\
\hline \multicolumn{2}{|l|}{ Water closet 1} & 6 & 1 & time & 48 \\
\hline \multicolumn{2}{|l|}{ Urinal 1} & 3.8 & 1 & time & 11 \\
\hline \multicolumn{2}{|l|}{ Basin tap 1} & 9 & 5 & secs & 6 \\
\hline \multicolumn{2}{|l|}{ Shower } & 13 & 8 & secs & - \\
\hline \multicolumn{5}{|c|}{ Sub-total (L) } & 65 \\
\hline \multicolumn{5}{|c|}{ Annual Consumption (m3) } & 270 \\
\hline
\end{tabular}




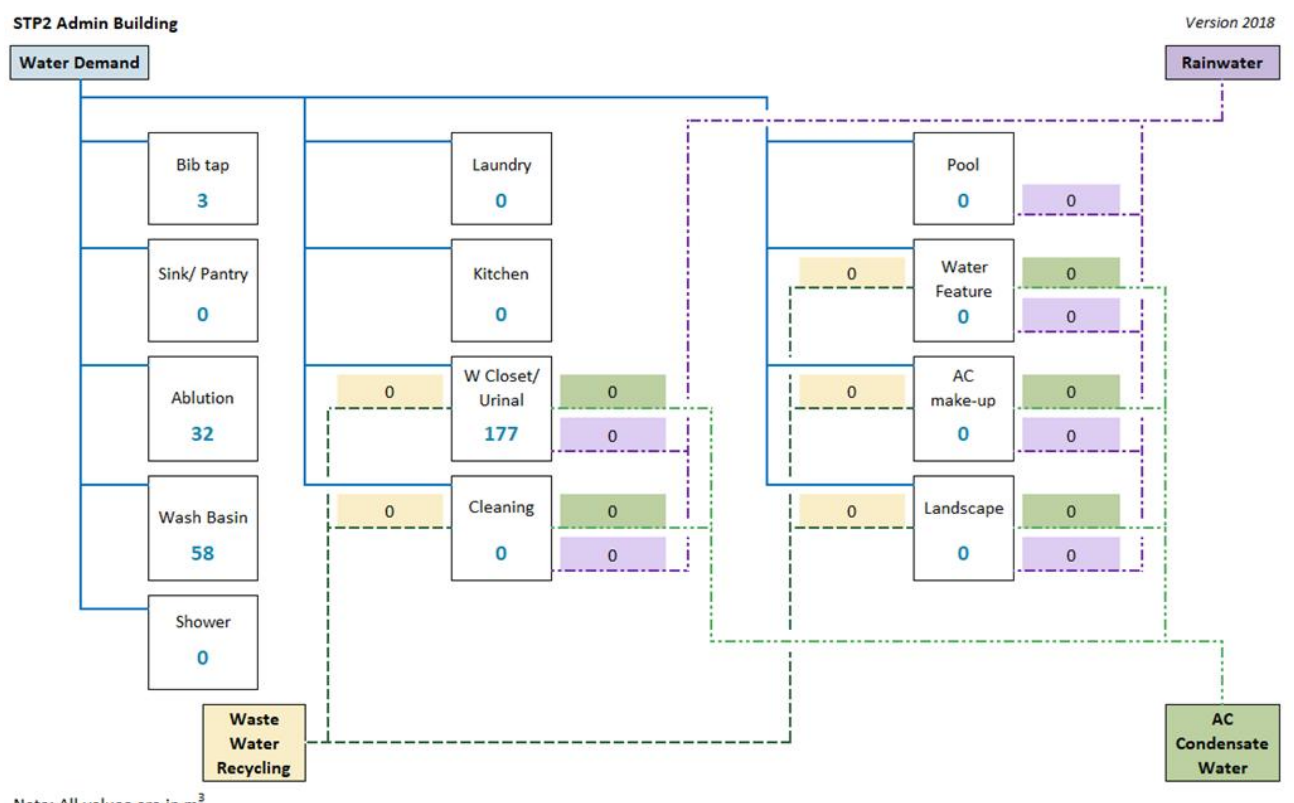

Notes to Water flow Diagram

"Benchmark Design"

- Total water demand $270 \mathrm{~m} 3$ per year, of which $177 \mathrm{~m} 3(65 \%)$ is related to WC flushing.

- No rainwater harvesting system is implemented, and all rainwater collected from roofs is diverted to the storm water drain.

- WC: $6 \mathrm{~L} /$ flush

- Urinal: $3.8 \mathrm{~L} /$ flush

- Basin tap: $9 \mathrm{~L} / \mathrm{min}$

- Ablution tap: $8 \mathrm{~L} / \mathrm{min}$

- No AC condensate Water

iv. Water "Current Building" Case

\section{Inputs to "Current Building" Model}

Occupancy \& Schedules: For the all cases the water demand is based on assumed office occupancy of 30 FTE (50\% male / 50\% female), working standard office hours. This are input to calculate the daily and annual water consumption.

Water Fitting: For the benchmark case, more water efficient fixtures with efficiency rated flow-rates are taken. WC single flush: 6/flush, Urinal: $3.8 \mathrm{~L} /$ flush, Basin tap: $6 \mathrm{~L} / \mathrm{min}$, Ablution tap: $6 \mathrm{~L} / \mathrm{min}$.

Rainwater harvesting: included in current building case.

\section{Outputs from "Current Building" Model}

- Daily potable water consumption 863 (from 967 liter)

- Annual water consumption 243 m3. (Reduction of 10\%)

- $72 \%$ of all water use from toilet flushing

Total potable water reduced from benchmark $(27 \mathrm{~m} 3$ through more efficient fixtures $(10 \%))$, and $176 \mathrm{~m} 3$ through use of rainwater for toilet flushing (72\%). Potable water 
usage $243-176=67 \mathrm{~m} 3$

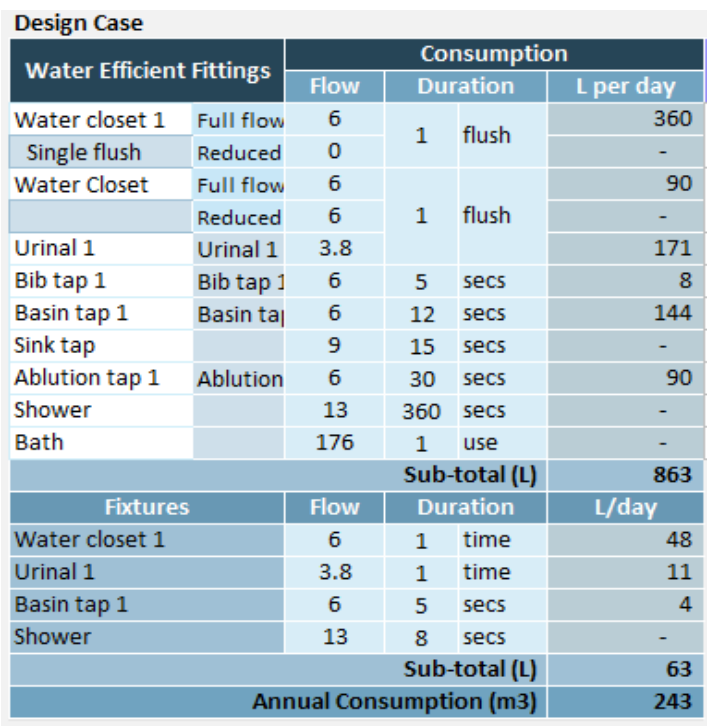

\section{Water flow diagram - Improvement Design}

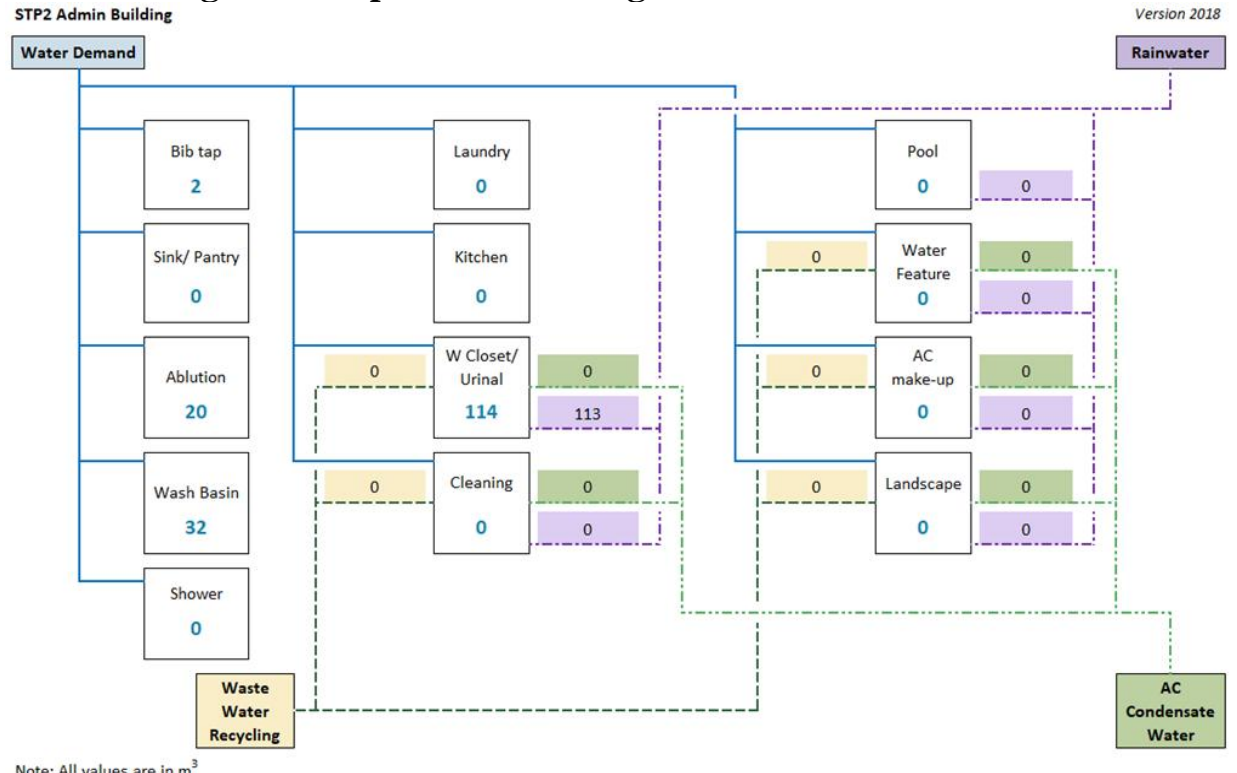

\section{Notes to Waterflow Diagram \\ “Optimised Design"}

- Total water demand 168m3 per year, of which $113 \mathrm{~m} 3(67 \%)$ is related to WC flushing.

- Rainwater harvesting system is implemented with a RWH tank of $80 \mathrm{~m} 3$. All rainwater collected from roofs is channelled to drains. Rainwater harvested is $113 \mathrm{~m} 3(100 \%$ of 
toilet flushing water)

- WC: $6 \mathrm{~L} /$ flush / 3L/flush

- Urinal: $1.5 \mathrm{~L} /$ flush

- Basin tap: $5 \mathrm{~L} / \mathrm{min} *$

- Ablution tap: $5 \mathrm{~L} / \mathrm{min} *$

- No AC condensate Water

\section{Discussions}

\section{Energy Efficiency - Summary of Results}

Energy Efficiency

Overall, BEI can be reduced by 46\% against the benchmark base building to Case 23 . Passive systems contribute to a reduction of $13 \%$, lighting $17 \%$ and air conditioning $16 \%$. Large reduction are provided by glazing performances, use of natural ventilation, office lighting and chiller performance. Total energy use per year by the building is reduced by $37,441 \mathrm{kWh}$. With energy tariff in Malaysia at RM0.51 per $\mathrm{kWh}$, this is a savings of $\underline{R} M 19,095$ (USD 4,640) per year.

Simulation software allowed a possibility to track each improvement case and show its effectiveness in reducing overall energy consumption and air conditioning load. Each individual case brings small contributions to overall energy savings. However, when all these small contributions are added up, a substantial overall energy saving is achievable.

\section{Water Efficiency - Results}

\section{Water Efficiency}

The baseline Benchmark water usage modelled on the GBI standard flow/flush rates indicates potable water usage of $270 \mathrm{~m} 3$ /year. This is set as the baseline to which the improvements are measured against. The Current Building is based on the current understanding of the implantation of water efficiency features. $27 \mathrm{~m} 3$ per year $(10 \%)$ can be more efficient basin and ablution taps to a water usage of $243 \mathrm{~m} 3 /$ year. An expected $176 \mathrm{~m} 3$ of rainwater is harvested for toilet flushing, which is the equivalent of 621 liter per day, This brings the amount of potable water use down to $67 \mathrm{~m} 3 /$ year, a reduction of $72 \%$. The Optimised Design further improves the efficiency of flow/fixture rates from the base case by $33 \%$ through the use of dual flush WC, and the urinal to a water efficient urinal to $180 \mathrm{~m} 3 /$ year. An expected $113 \mathrm{~m} 3$ rainwater harvested for toilet flushing. This brings the amount of potable water use down to $55 \mathrm{~m} 3 /$ year, a reduction of $62 \%$.

\section{Conclusion - Energy Efficiency "Managed"}

What is the level of sustainable practices relate to Energy Efficiency for Pantai 2 STP

GBI recognises that baseline BEI for offices is approximately $220 \mathrm{~kW} / \mathrm{m} 2 /$ year. This is based on Malaysia average energy use in office buildings derived from actual performance data that include various office building typologies and age.

\section{1. $\underline{\mathrm{BEI}}=120.45 \mathrm{kWh} / \mathrm{m} 2 /$ year}

Based on our simulation results the Base building represents Case 1

(Benchmark) and is equal to $\underline{B E I}=120.45 \mathrm{kWh} / \mathrm{m} 2 /$ year. This would be a $45 \%$ reduction compared to the average office building, with a significant 
contributor being the relatively low Window to Wall ratio of $21 \%$.

\section{2. $\mathrm{BEI}=64.40 \mathrm{kWh} / \mathrm{m} 2 /$ year}

The implementation of the 22 design enhancements will allow the BEI to by $46 \%$ from the Baseline. Passive strategies are able to reduce the BEI by approximately $13 \%$. Lighting strategies by a further $17 \%$, and cooling strategies by another $16 \%$ To bring the total building BEI down to $64.40 \mathrm{~kW} / \mathrm{m} 2 /$ year.

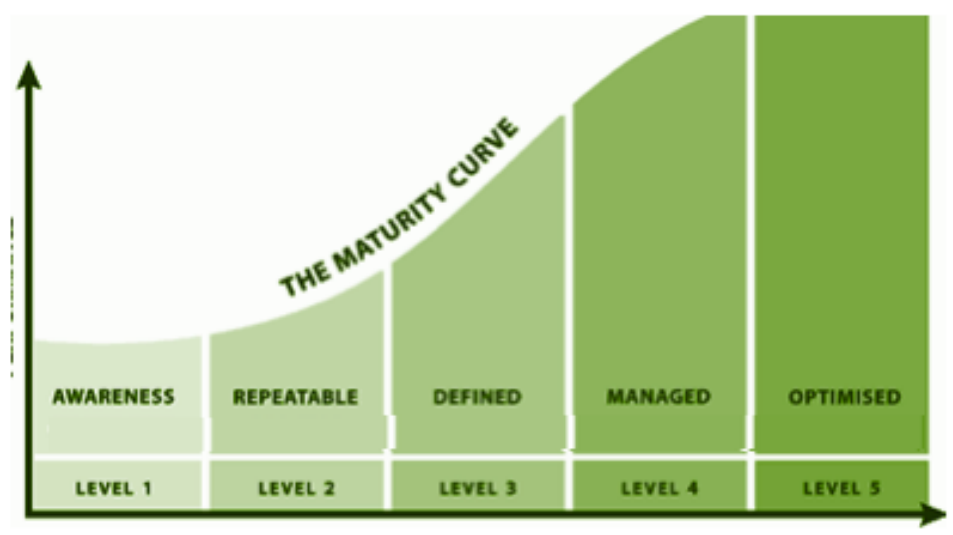

Overall level of sustainable Energy Efficiency is assessed to be Level 4 "Managed" with an expected BEI between the Base and the Optimised Case. Conclusion - Water Efficiency "Managed"

What is the level of sustainable practices relate to Water Efficiency for Pantai 2 STP?

The second scenario (current building case) is reasonable representations of the The Administrative Office Building of the Pantai STP 2 Plant

The building has a modelled water consumption of $243 \mathrm{~m} 3$ which is $10 \%$ below the GBI established benchmark of $270 \mathrm{~m} 3 /$ year given the occupancy and schedules. When combined with a rainwater harvesting tank used for the toilet flushing, the potable water demand is reduces significantly to $67 \mathrm{~m} 3 /$ year and a reduction of $72 \%$.

1. Water Efficient Fittings

Our simulation has modeled the current design case on $10 \%$ reduction. Although considered a good step in the right direction for New Constructions

a $>30 \%$ reduction is very feasible, and a $>50 \%$ for offices is possible. As detailed specifications were not available it may be the case the actual building performs better than modeled.

2. Rainwater Harvestings

Rainwater harvesting that leads to $>30 \%$ reduction in potable water consumption is considered "good", and a reduction in $>50 \%$ excellent. Our simulation indicates a reduction of well over $50 \%$ and therefore is considered "excellent" 


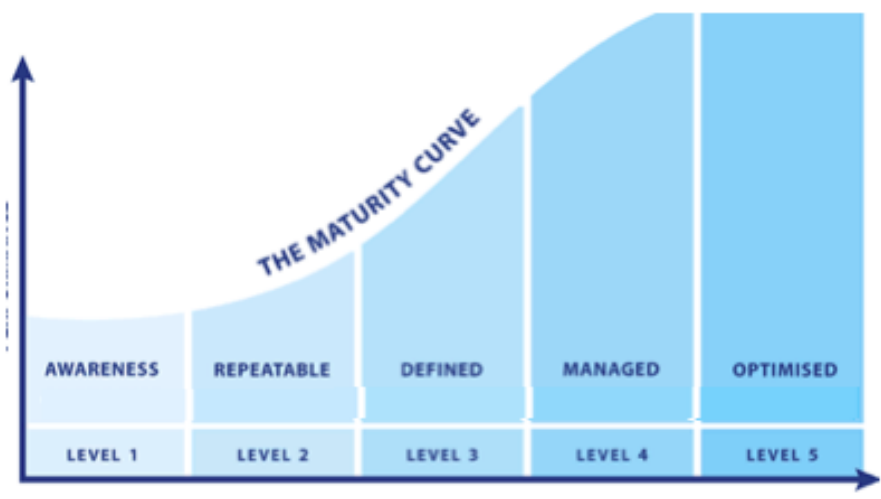

\section{Overall level of sustainable Water Efficiency is assessed to be Level 4 "Managed"}

\section{Conclusions and Suggestions}

For energy efficiency many of the design strategies are replicable, especially when new administrative office buildings are developed. As a result the targeted BEI should be substantially below that of average Malaysian offices. Several of the highlighted design principles that were modelled are observable in the Administrative Building (e.g. Window to Wall Ratio of $<30 \%$, Natural ventilated areas, efficient lighting, and efficient air-conditioning). If these are replicated, or even enhanced than new administrative office buildings should be able to achieve similar energy efficiency levels. For existing buildings there are often less parameters available to influence, but also in these cases significant reductions can be achieved.

In terms of water efficiency, the sustainable practices are effective and also replicable, especially when new administrative office buildings are developed. Nowadays, Water Efficient fixtures and fittings are widely available, and with careful selection significant water savings can be achieved. A 30\% reduction is feasible in almost all cases. The use of treated rainwater for toilet flushing is less common, but can be a significant contributor to water efficiency. The project's rainwater harvesting system is one of the elements that does make the Pantai 2 STP Administrative Building a role model for other.

\section{References}

Alberto-Jesús Perea-Moreno Carmen de la Cruz-Lovera, José-Luis de la Cruz-Fernández, José Antonio Alvarez-Bermejo and Francisco Manzano-Agugliaro, (2017). Worldwide Research on Energy Efficiency and Sustainability in Public Buildings

Isaac B. Addo,Martin C. Thoms andMelissa Parsons. (2018) Barriers and Drivers of Household WaterConservation Behavior: A Profiling Approach.Water 2018, 10(12), 1794; https://doi.org/10.3390/w10121794

Lekshmanan, Ramya. (2015). Energy Conservation - A Case Study. International Journal of Applied Engineering Research ISSN 0973-4562 Volume 10, Number 9.

Montoya, F.G.; Peña-García, A.; Juaidi, A.; Manzano-Agugliaro, F.(2017). Indoor Lighting Techniques: an overview of evolution and new trends for energy saving. Energy Build. 2017, 140, 50-60. 
Perea-Moreno, A.J.; García-Cruz, A.; Novas, N.; Manzano-Agugliaro, F.(2017) Rooftop analysis for solar flat plate collector assessment to achieving sustainability energy. J. Clean. Prod. 2017, 148, 545-554

Sheth, Dr. (2017). Water Efficient Technologies for Green Buildings. International Journal of Engineering Innovation and Scientific Research ISSN (online) 2395 - 6372. Vol.1 (3). P.P. 5-10.

Smith, H.M.; Brouwer, S.; Jeffrey, P.; Frijns, J.(2018) Public responses to water reuse-Understanding the evidence. J. Environ. Manag. 2018, 207, 43-50.

Zhao, L.; Zhou, Z.(2017). Developing a Rating System for Building Energy Efficiency Based on In Situ Measurement in China. Sustainability 2017, 9, 208. 